\title{
Sarau Asas Abertas: memórias e resistência em forma de imagens visuais e de poemas ${ }^{1}$
}

\section{Sarau Asas Abertas: memories and resistance in form of visual images and poems}

\author{
Barbara Heller², Vima Lia de Rossi Martin³, Anderson William \\ Marzinhowsky Benaglia ${ }^{4}$, Fernanda Mendes Soares Barreiros ${ }^{5}$
}

\footnotetext{
1 Este artigo é fruto de pesquisas realizadas no âmbito do grupo Liberdades Poéticas, que atua com remição de pena por leitura na Penitenciária Feminina da Capital (PFC) desde 2020. De 2017 a 2019, o mesmo trabalho foi realizado pelo grupo Travessias. Universidade Paulista (Unip) e coordenadora do grupo Liberdades Poéticas. E-mail: b.heller.sp@gmail.com. Liberdades Poéticas. E-mail: anderson.wbe@hotmail.com. 


\section{Resumo}

Analisamos, neste artigo, o livro Sarau Asas Abertas, coletânea de poemas de mulheres aprisionadas na Penitenciária Feminina da Capital (PFC), publicada em 2019 pelo Coletivo Poetas do Tietê. Contextualizamos o estado atual do sistema prisional brasileiro com dados concretos, fundamentais para a compreensão da condição das mulheres em situação de privação de liberdade. Com o suporte de autores que vão da literatura à memória social, identificamos estratégias de resistência à invisibilidade e ao silenciamento por meio de seus textos e das imagens visuais que compõem suas capas e contracapas. Chamamos atenção, ainda, para a importância de iniciativas que priorizam grupos sociais excluídos e estigmatizados nas e pelas mídias e sua contribuição para a problematização da memória pública.

\section{Palavras-chave}

Literatura, resistência, memória, Penitenciária Feminina da Capital.

\section{Abstract}

This article analyzes the book Sarau Asas Abertas - a collection of poems written by women prisoners at the Penitenciária Feminina da Capital (PFC), published in 2019 by the Poetas do Tietê collective. To understand the condition of women deprived of liberty, we contextualize the current state of the Brazilian prison system using concrete data. Based on authors who range from literature to social memory, we identify a set of strategies for resisting invisibility and silencing executed through their texts and the visual images displayed on its covers and back covers. We also call attention to the importance of initiatives prioritizing social groups excluded and stigmatized in and by the media and their contribution to problematizing public memory.

\section{Keywords}

Literature, resistance, memory, Penitenciária Feminina da Capital. 


\title{
Introdução
}

Grupos sociais subalternos têm sido cada vez mais valorizados pelos estudiosos da memória social, como mostram os textos de Beatriz Sarlo (2007) e Márcio SeligmanSilva (2003). As vítimas de regimes autoritários, do nazifascismo ou de ambos podem ser contabilizadas aos milhões, e suas histórias, ainda que individuais, acabam por compor o que entendemos por memória coletiva, como explica Maurice Halbwachs:

\begin{abstract}
[A memória individual] não está inteiramente isolada e fechada. Um homem, para evocar seu próprio passado, tem frequentemente necessidade de fazer apelo às lembranças dos outros. Ele se reporta a pontos de referência que existem fora dele, e que são fixados pela sociedade. Mais ainda, o funcionamento da memória individual não é possível sem esses instrumentos que são as palavras e as ideias, que o indivíduo não inventou e que emprestou de seu meio. (1990, p. 54)
\end{abstract}

Apesar das pesquisas recentes, que agora permitem reconhecer esse enorme contingente de indivíduos até então silenciados, há outros que, no Brasil, vivem de maneira quase invisível, com raras possibilidades de se fazerem conhecer e de construírem uma identidade coletiva. Privados da liberdade de ir e vir, vivem sob a custódia do Estado em unidades prisionais muitas vezes distantes de suas cidades de origem, condição que os deixa ainda mais isolados.

Poucas são as iniciativas que tratam de garantir a expressão da voz das 753.966 pessoas presas no Brasil, que, em 2020, ocupavam as unidades prisionais e as carceragens das delegacias ${ }^{6}$. Por isso, priorizamos, para o presente artigo, divulgar e analisar uma obra que deu visibilidade a esse grupo de pessoas tido, para o senso comum, como indesejável. Trata-se do livro Sarau Asas Abertas (2019), em que é possível reconhecer a constituição de vínculos por meio de processos comunicativos híbridos (textos e colagens nas capas e contracapas) e contato entre dois espaços até então intocáveis, o prisional e o extramuros. destacar que, a princípio, na Tela 1 é apresentado o número de 702.069 pessoas presas, entretanto, avançando no documento encontramos dados que sugerem esse número ser ainda maior, ao apresentá-lo pela faixa etária da população prisional: 753.966 pessoas (Tela 6 ). 
Conforme ensina Baitello Júnior (1998), o fenômeno comunicacional ocorre por meio do "uso de ferramentas comunicativas com a finalidade de amplificar suas mensagens no tempo, espaço ou na intensidade" (p. 13). Ao longo do artigo, verificaremos quais são essas ferramentas e como elas funcionam na mídia livro. Especialmente na contemporaneidade, quando novos suportes concorrem com textos impressos, é necessário transformá-los.

\footnotetext{
em produtos editoriais bem cuidados, [para que operem] com os mais variados sentidos do corpo e da mente: visual, porque apresentam capas e contracapas com design atraente; tátil, porque a gramatura das páginas e das capas agradam ao toque; emocional, porque contam histórias de vida permeadas de ameaças e superação; intelectual, porque informam dados até então pouco conhecidos de eventos e de personagens, entre outros. (HELLER; VARGAS, 2020, p. 38, grifos dos autores)
}

Instigados a procurar atender às várias provocações sugeridas pelo livro Sarau asas abertas, optamos por trabalhá-lo de "fora para dentro", isto é, do contexto social para os poemas propriamente ditos. Passamos pela discussão sobre as noções de exclusão e de resistência por meio da literatura, pelas condições atuais do sistema carcerário brasileiro e, finalmente, pela literatura do cárcere e sua relevância para a memória pública. Acreditamos que, assim, os poemas selecionados para análise na última seção do artigo ganham envergadura, pois ultrapassam os sentidos primeiros dos versos: são a simbolização das experiências das autoras, a ativação de suas memórias e a construção de um espaço interior de resistência frente à desumanização promovida pelo sistema prisional.

\section{Exclusão e resistência por meio da literatura}

A noção de exclusão é complexa e movediça e perpassa diferentes campos do saber, sendo frequentemente mobilizada a partir do binômio inclusão/exclusão, o que, por si só, não atenua sua imprecisão, haja vista a importância de se contextualizarem os referentes capazes de circunscrever e atribuir sentidos a essa experiência humana. 
Compreendida em uma concepção dialética, como processo sócio-histórico, a exclusão pode se configurar ao menos em três dimensões, como bem aponta Sawaia no livro As artimanhas da exclusão: análise psicossocial e ética da desigualdade (2001): a dimensão objetiva da desigualdade social, a dimensão ética da injustiça e a dimensão subjetiva do sofrimento. A partir dessa distinção, é possível pensar que, sob o ponto de vista social e jurídico, os mecanismos de inclusão/exclusão dão sustentação aos Estados contemporâneos, que buscam incessantemente desenvolver formas de controle soberano sobre a vida e a morte dos indivíduos, estabelecendo o que Agamben (2004) reconhece como "Estados de exceção".

Nessa perspectiva, a exclusão é consequência (e condição) da desigualdade social sistêmica engendrada e administrada por poderes autoritários, ainda que travestidos de democráticos. Essa realidade política impacta não apenas a existência material das pessoas, como também o seu psiquismo, uma vez que os sujeitos, sempre em relação com outros sujeitos, desenvolvem formas próprias de sentir e estar no mundo. Nas palavras de Sawaia:

A dialética inclusão/exclusão gesta subjetividades específicas que vão desde o sentir-se incluído até o sentir-se discriminado ou revoltado. Essas subjetividades não podem ser explicadas unicamente pela determinação econômica, elas determinam e são determinadas por formas diferenciadas de legitimação social e individual, e manifestam-se no cotidiano como identidade, sociabilidade, afetividade, consciência e inconsciência. (2001, p. 9)

Ao evidenciar um sofrimento ético-político associado à exclusão, Sawaia problematiza noções como norma, adaptação e culpa e abre espaço para a percepção de diferentes formas de subjetivação. Segundo a autora, a depender das experiências individuais, esse sofrimento pode ser nomeado de diversas maneiras e valorado com intensidades distintas. Entretanto, de modo geral, o que se observa a partir do relato de pessoas pertencentes a diferentes categorias de excluídos é uma mesma "dor que surge da situação social de ser tratado como inferior, subalterno, sem valor, apêndice inútil da sociedade" (SAWAIA, 2001, 
p. 104). Trata-se de uma mutilação da vida que traz, em sua base, a consciência do sentimento de desvalor e o desejo de reconhecimento.

Nessa chave para o enfrentamento da exclusão, Sawaia propõe uma práxis psicossocial com o entrelaçamento de duas estratégias concomitantes: uma de ordem material e jurídica, que é principalmente de responsabilidade do poder público, e outra de ordem afetiva e intersubjetiva, que é tarefa de todos e de cada um de nós. Essa segunda estratégia corresponde ao fortalecimento da legitimidade social a partir do fortalecimento da legitimidade individual, articulando as dimensões coletiva e pessoal. Assim, a conexão das noções de cidadania e de cuidado pode se desdobrar, por exemplo, em ações culturais e literárias capazes de favorecer a reorganização de vínculos entre os sujeitos e sua interioridade e entre os sujeitos e a sociedade que exclui.

No sentido de contribuir para a reflexão sobre enfrentamento da exclusão, a noção de "resistência" pode ser mobilizada para se pensar os mais diferentes modos de expressão da tensão entre os sujeitos e o mundo, capazes de desalienar percepções e ações automatizadas.

Alfredo Bosi, em seu texto "Narrativa e resistência" (2002), nos lembra que "resistência" é um conceito de ordem originariamente ética, e não estética, e significa, em uma acepção simples, opor a própria força a uma força externa. No entanto, esse conceito transita também para uma dimensão estética, na medida em que as formas de existir e resistir são múltiplas, ligando-se tanto às potências cognitivas da intuição e da razão, como às potências da práxis que são tomadas por ações e projetos políticos. É essa complexidade conceitual que torna possível falarmos, ainda segundo Bosi, em "poesia de resistência" ou "narrativa de resistência".

Na concepção proposta pelo autor, a literatura é compreendida como um espaço essencial de elaboração estética de histórias e narrativas. Ler e escrever literatura seriam, assim, possibilidades de deslocar para o campo da linguagem representações de situações diversas compartilhadas pela experiência humana. Parte dessas experiências dizem respeito ao conjunto de transformações políticas, 
sociais e econômicas que expõem milhares de homens e mulheres a condições de vulnerabilidade e violência generalizada, perpetuando um estado permanente de crise.

Michèle Petit, em seu livro A arte de ler, ou como resistir à adversidade (2009), desenvolve o efeito de tais crises em um âmbito mais subjetivo, sublinhando como situações vividas na forma de rupturas de laços ou de paisagens familiares confinam o sujeito em um tempo imediato, em um espaço sem linha de fuga, sem perspectiva de projetos, futuro ou continuidade de si. As crises guardariam, assim, uma profunda relação com os processos de exclusão.

No pensamento da autora, a noção de resistência também se liga à experiência com o literário. Para ela, a literatura constitui-se como um espaço de encontros personalizados, intersubjetivos, em que o devaneio leva à construção de um mundo interior, de um espaço psíquico. A leitura de textos literários teria um papel fundamental em contextos críticos, pois tornaria possível uma elaboração narrativa: "a leitura convoca uma atividade de simbolização, de pensamento, de narração de sua própria história entre as linhas lidas, uma costura de episódios vividos de maneira fragmentada" (PETIT, 2009, p. 83). Para além das reparações íntimas, a apropriação da literatura também se traduziria na apropriação de uma linguagem capaz de dar forma a experiências e sentimentos, conferindo novos sentidos e valores poéticos para a vivência humana. Desse modo, a leitura pode ser vista como um caminho para os indivíduos articularem suas próprias intenções e manifestarem-se também no processo complementar da escrita, como autores de suas próprias narrativas de resistência.

Isso posto, entendemos a obra Sarau Asas Abertas como espaço privilegiado de resistência, tal como formulam Alfredo Bosi e Michéle Petit. Gerado no ambiente prisional, os textos verbo-visuais que compõem o volume permitem ver e entrever potências cognitivas da intuição e da razão, bem como uma elaborada narração da própria história.

A dimensão do livro cresce aos olhos do(a) leitor(a) na medida em que passa a conhecer, por meio de dados concretos, as condições atuais do sistema carcerário no Brasil, o que justifica a seção que segue. 


\section{"Não temos muitos presos no Brasil, na verdade temos poucas vagas"}

A frase que tomamos emprestada para abrir esta seção foi proferida em 14 de fevereiro de 2020, por Fabiano Bordignon, diretor geral do Departamento Penitenciário Nacional (Depen), para quem, mais do que reduzir o número de pessoas em situação de prisão, é necessário aumentar a quantidade de vagas nos presídios nacionais (NASCIMENTO, 2020).

O Brasil possui um déficit de 231.768 vagas para atender a população carcerária total ${ }^{7}$. Sobre a conjuntura geral do sistema prisional, quase $30 \%$ das pessoas que se encontram em privação de liberdade são presos provisórios "que ainda não foram condenados", segundo Bordignon ${ }^{8}$.

Esses números apontam que as políticas federais são tão eficientes no fomento à retenção de pessoas que o Brasil ocupa, atualmente, o terceiro lugar no ranking dos países com maior população carcerária no mundo (atrás apenas da China e dos Estados Unidos). O caráter massivo do encarceramento prisional no país, que leva à superlotação das cadeias, está intimamente relacionado ao racismo que estrutura a sociedade brasileira. Segundo a Assembleia Legislativa do Estado do Rio Grande do Sul, "o sistema penal desvela-se não como remédio à 'criminalidade', como oficialmente se declara, mas como perseguidor de corpos negros de mulheres e homens" (RIO GRANDE DO SUL, 2017, p. 4) ${ }^{9}$.

O mesmo documento comenta as mazelas dos encarcerados: maus-tratos, falta de condições sanitárias, medicalização intensiva e arbitrária e "prisões abusivas, ilegais e discriminatórias executadas contra as pessoas mais pobres desse país e do crescente investimento em políticas repressivas em detrimento de políticas sociais" (RIO GRANDE DO SUL, 2017, p. 8). 
A quase totalidade dos presos é do sexo masculino: são quase $90 \%$. As mulheres, embora em percentual reduzido, têm sido cada vez mais encarceradas graças à sua posição social subalterna e à falta de recursos para prover suas vidas:

Bom lembrar que a maioria das mulheres presas por tráfico é composta por pequenas comerciantes ou mesmo por meras usuárias (fenômeno também observado entre os homens) e que não são raros os casos de separação violenta e ilegal dessas mulheres e de seus filhos. Também não são raros os casos de mulheres que, presas durante a gravidez, ou perdem a criança por falta de cuidados médicos ou dão à luz algemadas ou, ainda, no chão, sobre sacos de lixo. (RIO GRANDE DO SUL, 2017, p. 5)

Para compreender as especificidades do encarceramento feminino no país, importa considerar que, embora o número de mulheres presas (cerca de 36.999) seja bastante inferior ao número de homens (aproximadamente 716.967), segundo dados mais recentes do Depen ${ }^{10}$, elas é que são miradas pelas atuais políticas de encarceramento desencadeadas pela guerra às drogas. O tráfico de substâncias ilegais é responsável por, aproximadamente, 58\% das suas prisões, enquanto, no caso dos homens, é de apenas $31 \%{ }^{11}$.

Em geral, as mulheres que entram no sistema prisional são jovens, negras, solteiras com filhos, têm baixo nível de escolaridade e renda familiar precária. Antes da prisão, não tinham estabilidade financeira e desempenhavam ocupações de baixa qualificação ou se encontravam desempregadas. Esse grupo social é frequentemente marcado por violência doméstica, núcleos familiares instáveis e pouco acesso à educação.

O encarceramento, para a população feminina, representa uma ruptura ainda mais significativa com a liberdade e com os laços de parentesco, pois as mulheres são mais frequentemente abandonadas pelos companheiros e parentes. Além disso, por serem mães, em parte significativa dos casos, são

10 Disponível em: https://bit.ly/3fnuoCl. Acesso em: 17 mar. 2021. Dados em Informações Gerais, Tela 15 - População Prisional por Gênero. 
afastadas do convívio cotidiano com os filhos, condição que intensifica, por um lado, o sofrimento e sentimento de culpa e, por outro, o desarranjo dos núcleos familiares que, predominantemente, em nossa sociedade, têm, na figura da mãe, a cuidadora e a responsável pela manutenção do lar e pela educação dos filhos.

Nosso artigo atém-se à realidade da Penitenciária Feminina da Capital (PFC), no bairro do Carandiru, Zona Norte da cidade de São Paulo, pois foi nela que o projeto Sarau Asas Abertas se constituiu, como veremos adiante. Localizada no antigo complexo do Carandiru, que anteriormente também abrigava as penitenciárias masculinas desativadas entre 2002 e 2005, em decorrência do massacre ali ocorrido em 1992, sobreviveu às transformações do lugar.

Unidade de regime fechado, abriga pouco mais de 450 mulheres e concentra quase toda a população feminina estrangeira que aguarda julgamento ou cumpre pena no Estado. Seus extensos muros separam-na das movimentadas avenidas da Zona Norte de São Paulo e é preciso cruzar o Parque da Juventude, anteriormente ocupado pelos demais pavilhões masculinos, se o acesso a ela se der pelo sistema metroviário. Este parque abriga hoje o Museu Penitenciário Paulista, dedicado a preservar a história do sistema prisional do estado de São Paulo.

\section{Memória pública e literatura produzida no cárcere: gênese do Sarau Asas Abertas}

Como lembra Seligmann-Silva (2003), as novas teorias nascidas no campo dos Estudos Sociais tentam corresponder à demanda de evidenciar o discurso do Outro, do sujeito que havia sido recalcado e impedido de falar até recentemente. O autor salienta a importância crescente dos estudos sobre a memória "na nossa era que pretende redesenhar o homem e sua 'humanidade'" (p. 31) e, ao tratar de textos literários escritos sobre experiências traumáticas, elabora as seguintes perguntas: quanto do "real" é de fato apresentado? Quem é esse(a) autor(a), que conta suas experiências carcerárias em condições adversas? Quão verossímil é a sua produção para que possamos acreditar nelas? 
Essas são algumas questões que os estudos da memória no Brasil têm formulado, seguindo uma tendência latino-americana que tem em Beatriz Sarlo uma de suas referências. Em sua obra Tempo passado (2007), a autora afirma que o passado irrompe no presente, sem suspendê-lo, e ainda projeta o futuro. Todas essas ativações da memória são materializadas por narrativas que, quando produzidas por "sujeitos marginais", demandam "novas exigências de método e tendem à escuta sistemática dos 'discursos da memória': diários, cartas, conselhos, orações" (2007, p. 17).

Na contemporaneidade, esses "sujeitos marginais", referidos por Sarlo, ou o "Outro", por Seligmann-Silva, podem ser o imigrante, o trabalhador, o desempregado, o jovem, o idoso, o encarcerado e a encarcerada, para citar apenas alguns. Essas pessoas, ao elaborarem suas narrativas a partir das próprias experiências, desestabilizam a chamada "memória pública", assim entendida por Elizabeth Jenin: "o entrelaçamento de tradições e memórias individuais, afetadas pelas prerrogativas de algumas vozes não só mais poderosas, mas também com mais acesso às arenas públicas" (JELÍN, 2017 apud SANGLARD; SANTA CRUZ, L.; GAGLIARDI, 2020, p. 7-8).

Ainda segundo a mesma autora, quando impedidos de expressar suas memórias pelas forças que endossam a versão oficial dos fatos, homens e mulheres buscam canais alternativos de expressão, para que possam materializar sua memória, renovando, assim, sua força e potência:

[...] não há pausa, não há descanso, porque a memória não foi depositada em nenhum lugar, tem de ficar nas cabeças e nos corações das pessoas. A questão de transformar os sentimentos pessoais, únicos e intransferíveis, em significados coletivos e públicos, permanece aberta e ativa. (2001, p. 103 , tradução dos autores $)^{12}$

Jelín ainda observa que os relatos das mulheres silenciadas assumem dimensão política, especialmente quando passam da condição de vítimas para 
a de testemunhas. Embora a autora esteja se referindo, na citação abaixo, às mulheres coreanas presas e exploradas sexualmente no Japão durante a Segunda Guerra Mundial, suas considerações sobre a memória pública e sua contestação vêm ao encontro da nossa discussão:

Neste caso, o processo de "dar voz às emudecidas" é parte da transformação do sentido do passado, que inclui redefinições profundas e reescritas da história. Sua função é muito mais que a de enriquecer e complementar as vozes dominantes que estabelecem o marco para memória pública. Mesmo sem intenção e sem ter consciência das consequências de sua ação, estas vozes desafiam a estrutura a partir da qual a história estava sendo escrita, questionando o marco interpretativo do passado. (2001, p. 112, tradução dos autores) $)^{13}$

As memórias produzidas por mulheres em situação de privação de liberdade permitem observar que, independentemente dos delitos cometidos, a rememoração favorece a desalienação e contribui para a problematização da memória pública.

Mais uma vez retomamos Márcio Seligmann-Silva, que entende a literatura carcerária na chave do traumático, afinal, as realidades vividas pelas pessoas encarceradas são de violência extrema e seu esforço de elaboração do vivido através da linguagem se apresenta como possibilidade de representação do sofrimento até então indizível, abrindo caminho para a restauração psíquica e para o estabelecimento de redes de solidariedade.

É assim que, no âmbito dessa produção testemunhal, a "literatura recupera seu compromisso com a mudança social e assume seu lugar nas lutas políticas" (SELIGMANN-SILVA, 2003, p. 35).

O livro Sarau asas abertas: mulheres poetas - penitenciária feminina da capital (COLETIVO POETAS DO TIETÊ, 2019), entendido aqui como representante da recente produção literária do cárcere, foi publicado pelo Coletivo Poetas do Tietê y complementar las voces dominantes que establecen el marco para la memoria pública. Aun sin proponérselo y sin tomar conciencia de las consecuencias de su acción, estas voces desafían el marco desde el cual la historia se estaba escribiendo, al poner en cuestión el marco interpretativo del pasado". 
por ter concorrido e vencido o edital público VAI (Programa para a Valorização de Iniciativas Culturais), que visa apoiar financeiramente atividades artístico-culturais do município de São Paulo.

Para gerar a publicação da coletânea de poemas, que comentaremos a seguir, o projeto Sarau Asas Abertas, coordenado por Jaime José Teixeira Quiroga, ofereceu oficinas semanais de leitura e escrita criativa com as participantes. A realização de rodas de leitura e saraus, a concepção do livro e seu processo de feitura foram pensados coletivamente, de modo que as autoras pudessem imprimir, por meio de suas palavras, um pouco de suas singularidades.

A grande potência dessa obra está, portanto, na elaboração de um espaçosuporte em que as mulheres privadas de liberdade são capazes de conceber uma escrita autoral para se tornarem protagonistas de suas próprias narrativas. O que nasceu intramuros ganhou espaço em esferas sociais mais amplas, garantindo a circulação de uma memória alternativa à oficial.

\section{Capas e contracapas - análise das imagens visuais}

"A capa é o primeiro espaço visual de contato entre o livro e o leitor" e funciona como um "forte elemento mediador no consumo" (HELLER; VARGAS, 2020, p. 39). Além disso, contém elementos de significação dos discursos presentes na obra e são tão passíveis de análise quanto os textos que abrigam. Vistos em conjunto, todos esses elementos possibilitam uma compreensão mais aprofundada da obra.

A logomarca "Sarau Asas Abertas" empresta seu nome à obra que reúne poemas de 48 mulheres abrigadas na PFC (Figura 1). Sua figura feminina, cujas asas são páginas entreabertas de um livro, remete à ideia que subjaz o projeto desde seu início: escrever e ler são atos tão libertadores, que alçam seus autores e leitores aos céus. Corpos, até então presos e invisibilizados pelo sistema carcerário, ganham liberdade, leveza e materialidade. 


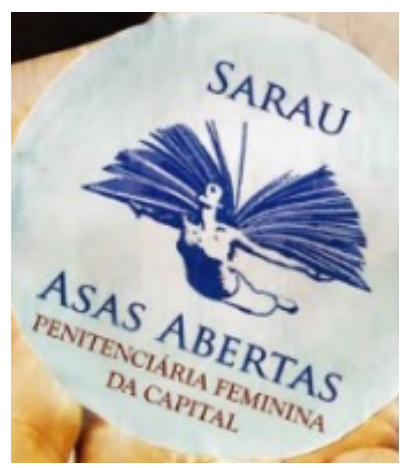

Figura 1: Logomarca do Sarau Asas Abertas

Fonte: Autores.

Os demais elementos imagéticos da capa e da contracapa, concebidos e produzidos pelas autoras, dialogam com o logo. A enorme mão que apoia o título da obra na primeira capa (Figura 2) parte do canto superior direito rumo ao centro, como se quisesse chamar a atenção dos leitores e lhes desejar as boas-vindas para a jornada que está para ser iniciada. Pode-se pensar ainda em uma mão que se estende para apoiar e acolher.

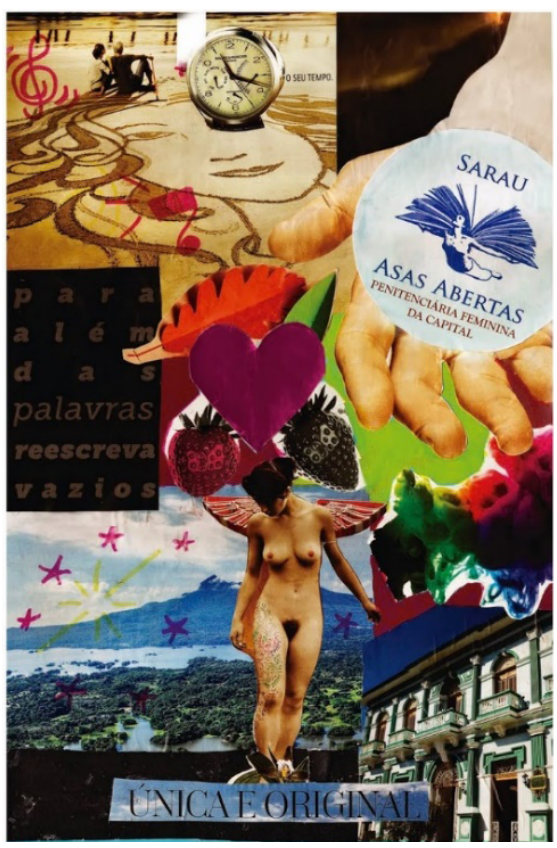

Figura 2: Capa do livro Sarau Asas Abertas

Diagramação de João Innecco, a partir de colagens feitas pelas mulheres da PFC Fonte: Autores. 
As outras imagens reforçam esses significados: a mulher nua e alada na metade inferior da capa, espécie de anjo caído, olha para baixo, criando uma tensão entre o voo sugerido por suas asas ainda abertas e pela aproximação do chão, que abriga o enunciado "única e original". Absolutamente livre, essa figura sexuada afronta a moral da cultura patriarcal, que deseja esconder e controlar os corpos e as mentes das mulheres.

O horizonte litorâneo e o relógio disposto na parte superior esquerda da capa, os morangos e o coração ao centro, a paisagem arquitetônica do quadrante inferior parecem representar os sonhos das autoras quando em liberdade: assumir o controle do tempo para que possam usufruir a natureza, para viajar, para experimentar alimentos improváveis no cotidiano prisional. Por meio de ações tão singelas no mundo livre, realizarão o desejo manifestado no enunciado "para além das palavras, reescreva vazios", que se vê à margem esquerda da capa.

No verso da capa (Figura 3), o leitor se depara com um fundo preto permeado por pontos e traços brancos, como uma noite estrelada. Esse céu noturno, que só pode ser visto através das janelas de suas celas, aflora outros sentimentos: nostalgia (quadrante superior esquerdo), carência (esquerda inferior), amor e fome (canto direito da parte central). 


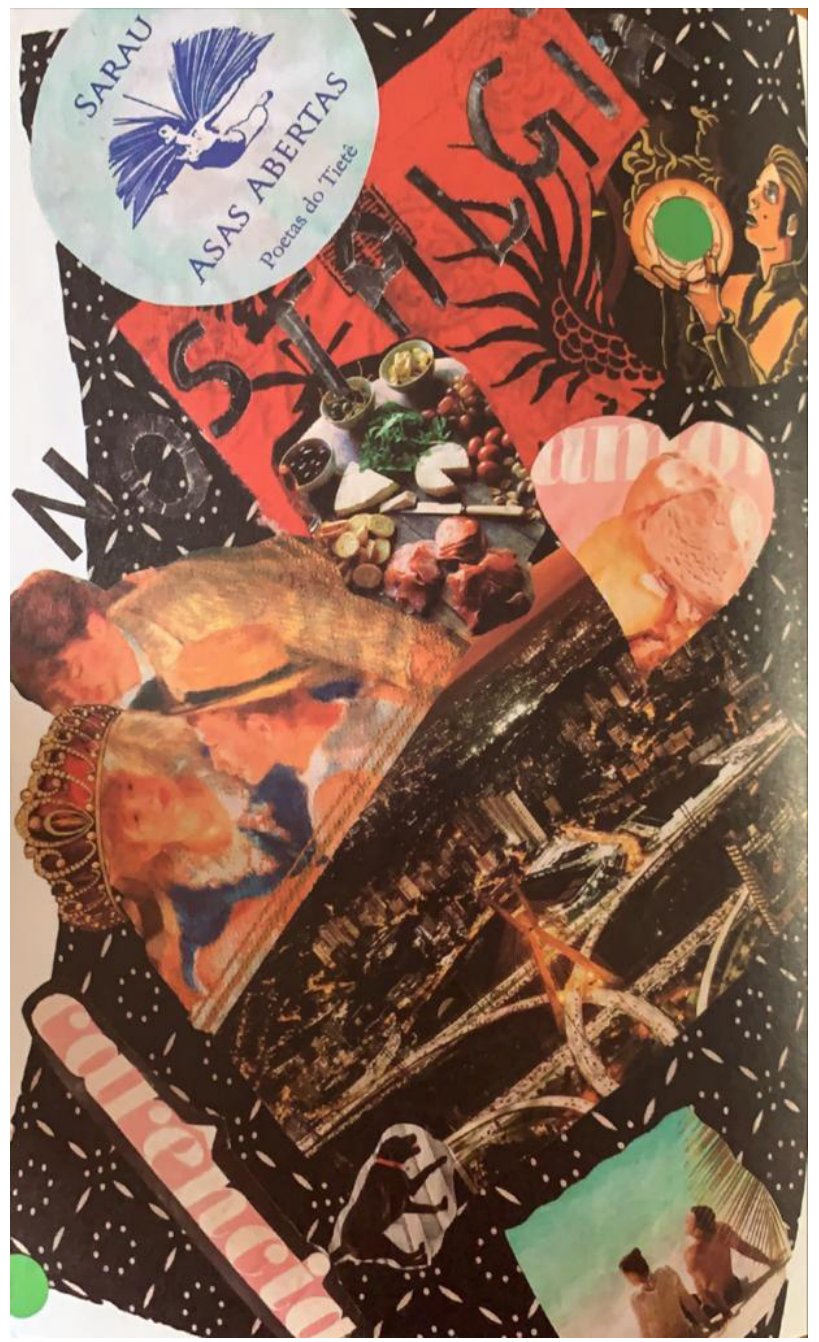

Figura 3: Verso da capa do livro Sarau Asas Abertas

Diagramação de João Innecco, a partir de colagens feitas pelas mulheres da PFC Fonte: Autores.

Ao mesmo tempo, também comparecem desejos já identificados na capa (Figura 1): uma paisagem urbana, aqui representada pela ponte estaiada da capital paulista (metade inferior) e alimentos (centro). Homens e mulheres ao ar livre (canto inferior direito e esquerdo) sugerem encontros fraternos e/ou amorosos.

O verso da contracapa (Figura 4) é tomado pela Mulher Maravilha, da editora norte-americana DC Comics, em plena ação. 


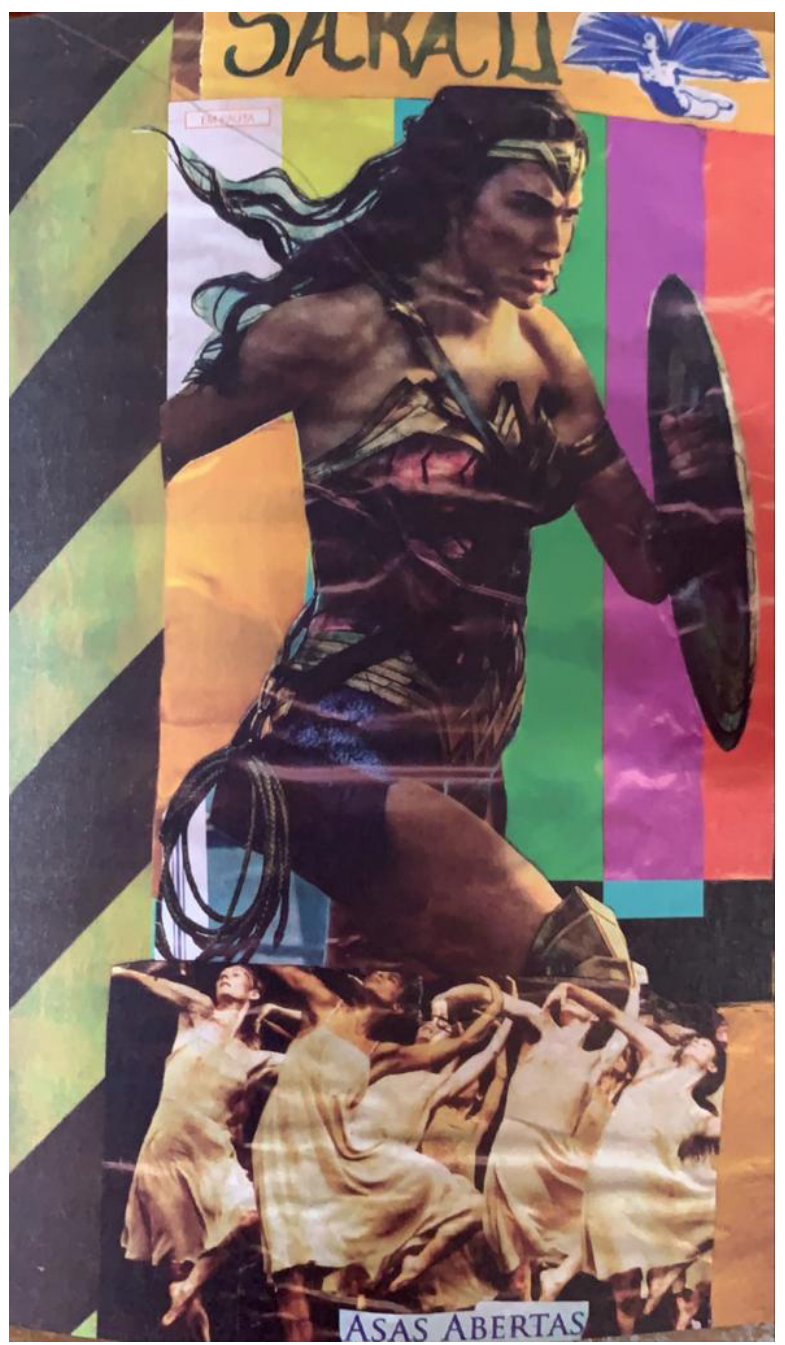

Figura 4: Verso da contracapa do livro Sarau Asas Abertas

Diagramação de João Innecco, a partir de colagens feitas pelas mulheres da PFC Fonte: Autores.

As figuras do anjo caído na capa (Figura 2) e da super-heroína (Figura 4) estão em relação dialógica. Enquanto a primeira rompe, com sua nudez e delicadeza, a ideia do recato, a segunda impõe sua força física por meio de seu corpo potente e em movimento. Ambas desafiam a ordem hegemônica masculina, mas são as dançarinas, ao pé da imagem, com suas roupas leves e cheias de movimento, que parecem sustentar a impetuosidade da Mulher Maravilha. A ideia que fica é que essas diferentes mulheres (ou as diferenças que constituem cada mulher) são igualmente apoiadas pelo coletivo Asas Abertas. 
A ideia de coletividade é reforçada na contracapa (Figura 5) por meio de imagens de alunos em sala de aula, de figuras humanas de cores variadas na parte superior, de silhuetas de mãos dadas e de pássaros que voam ao ar livre na borda inferior.

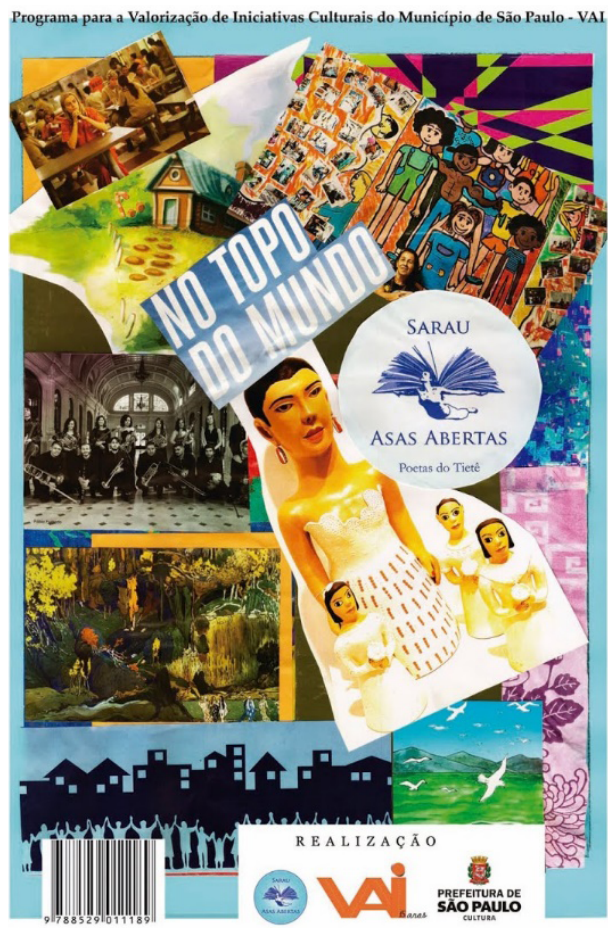

Figura 5: Contracapa do livro Sarau Asas Abertas

Diagramação de João Innecco, a partir de colagens feitas pelas mulheres da PFC Fonte: Autores.

O centro da imagem é ocupado por quatro bonecas de barro, sugerindo uma família matriarcal. As filham seguram flores, como se estivessem para ofertálas a alguém que não se vê, mas que está no horizonte do olhar da mãe. Sobre sua cabeça, o enunciado "no topo do mundo", registro que encerra a narrativa do empoderamento e resistência femininas iniciada nas imagens anteriores e sempre retomada nos poemas. 


\section{Os poemas - análise e sentidos}

Leitoras e leitores destes poemas se deparam com uma multiplicidade de vozes femininas que se valem muitas vezes de uma expressão memorialística para expor, de forma íntima, realidades marcadas por contextos de exclusão. O percurso traçado por cada uma delas é particular e diz respeito aos seus próprios processos de simbolização e ressignificação; no entanto, também se ancoram em um conjunto de experiências partilhadas que, embora únicas em seus modos de expressão, compõem um mosaico decorrente de situações análogas de desigualdade, vulnerabilidade e violência.

A situação do cárcere é vivida como exílio por muitas das mulheres encarceradas, especialmente as estrangeiras que estão deslocadas de suas paisagens habituais e sem familiares próximos. É assim, por exemplo, que Léa Campos descreve sua relação com a prisão no poema "Sentimento de exílio" (p. 68):

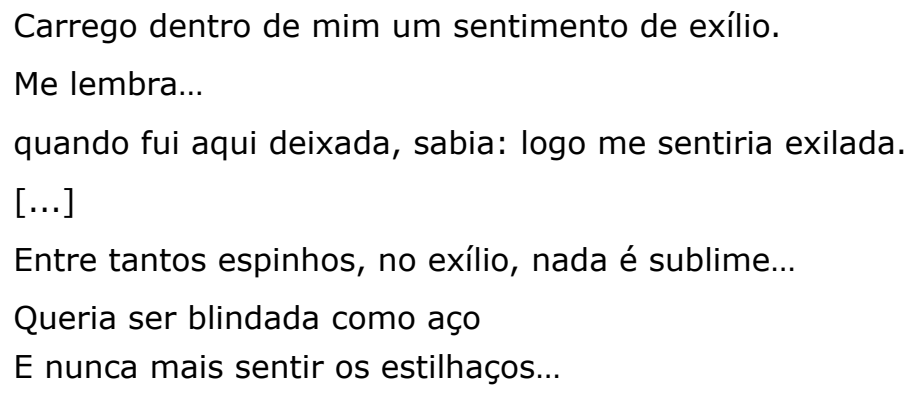

Não por acaso, a pesquisadora Michèle Petit estabelece uma valiosa relação entre literatura e exílio quando diz que

[...] é talvez antes de tudo à parte exilada de cada um que os livros, e mais ainda a literatura, se endereçam. A escrita literária é, em si mesma, em larga medida, uma tentativa de agarrar o que está perdido, faltando ou inacabado, de superar espaços, abolir fronteiras, reunir o que está separado, reconstituir terras desaparecidas, épocas passadas. (2009, p. 264-265)

O que percebemos à medida que lemos os textos dessas mulheres poetas da PFC, é a realização plena do exercício de entrelaçar, na escrita, as possibilidades individuais de cada uma delas de simbolizar suas experiências, reconstruir memórias 
e construir um espaço interior de resistência frente à desumanização promovida pelo sistema prisional.

A maternidade, por exemplo, é uma temática bastante explorada pelas autoras. Alguns de seus textos evocam a memória da gestação e partilham as expectativas criadas em torno desse período, durante o qual seus corpos abrigam outro ser humano, em formação. Nas palavras de Girlie S. Mojaki, no poema intitulado "Umbilical" (p. 49), esse momento se traduz assim:

maiores expectativas da vida uma criatura se criando em mim uma movimentada alma em mim

Já Nafy Lima qualifica como inexplicável - adjetivo que também dá título ao seu poema (p. 93) - as impressões e emoções causadas pelo seu gestar, e elenca cada uma de suas grandes esperas:

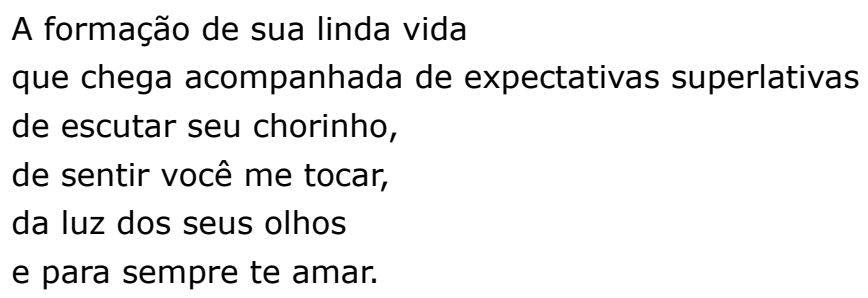

Essas expectativas parecem representar momentos ativados pela memória individual e coletiva de um estado em suspenso de uma felicidade já experimentada e que está novamente por vir. Monica Lorena Lemus Guzman também fala sobre a realidade concreta da maternidade marcada pelo encarceramento. No seu poema "A última memória" (p. 92), descreve seu derradeiro contato com a filha ainda pequena:

Minha filha tinha somente 2 anos de idade,

E no dia em que decidi viajar

Deixei minha filha sentada e não me despedi dela

Nem sequer consegui que ela

Me dissesse

"Mamãe". 
Outras mulheres também narram em textos a lembrança do instante em que se separam dos filhos e reconstroem, com o respaldo da linguagem literária, a experiência do distanciamento, da maternidade interrompida e do sentimento de culpa que as acompanha. Martha Paredes conta em "Coração Quebrado" (p. 87) sua dolorosa recordação:

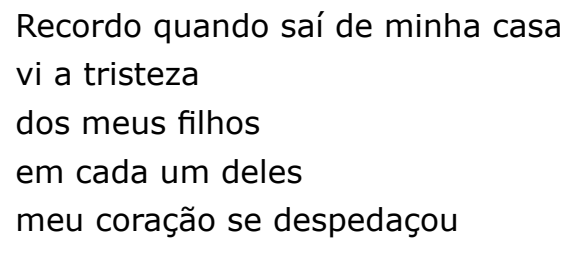

Marlese expõe no título de seu poema - "Minha querida filha" (p. 85) a intenção epistolográfica do texto, numa tentativa simbólica de fazer chegar até sua filha um pedido de perdão:

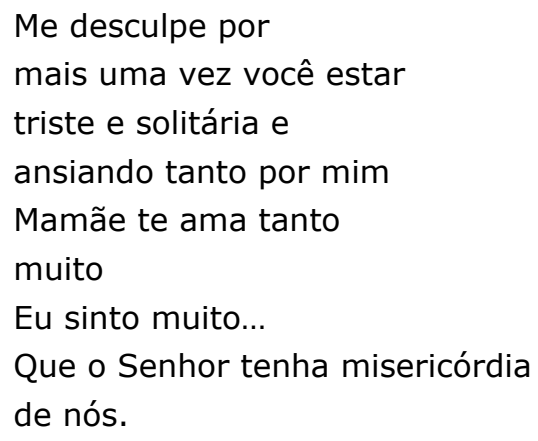

Os sentimentos e hesitações vividos no momento da prisão também aparecem na escritura dessas mulheres. O poema "Aeroporto" (p. 65), de Kamila Pontarolo, traz a imagem exata da abordagem policial que levou à sua detenção, reavivando as impressões dos instantes antes de conhecer seu destino.

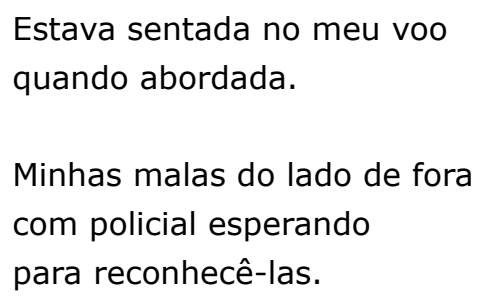


Neste momento, não sabia pra que rumo minha vida ia: se iria viajar ou se iria destruí-la.

Fernanda Simões Barreto da Silva, no poema "Pai" (p. 42), aborda sua entrada no sistema prisional: lendo o texto, somos capazes de visualizar a figura de seu pai, já de costas, deixando a filha retida na delegacia, quando possivelmente já não havia nada mais a fazer para evitar seu encarceramento. No momento da separação, a ênfase no Eu, marcada pela repetição do pronome pessoal, conota a dor da solidão:

Eu Eu Eu Eu Eu Eu

vendo você ir embora e me deixando ali naquela delegacia, nunca vai me sair da memória.

Na voz das mulheres detidas pela polícia também há denúncia e crítica social. Dagma Aparecida, em "Um sorriso em minha mente" (p. 22), diz que o estigma deixado por suas condenações no passado e o peso das palavras dos "homens de farda" foram responsáveis pelo seu regresso à prisão e pelo julgamento das pessoas da comunidade onde morava:

Passados 8 anos, em 2015, dessa vez sem saber o que eles pretendiam eles têm em sua consciência que eu não estava traficando, há muitos anos já não queria saber de nada de errado em minha vida - policiais invadiram a minha casa e mais uma vez tiraram a mãe de um filho. E como fiquei triste e muito nervosa.

[...] por já ter um passado fui julgada e condenada por pessoas que não acreditavam na minha inocência. Preferiram acreditar em homens de farda.

Já as palavras de Eliane de Castro, no texto "Nada como um dia após o outro" (p. 39), denunciam a prática do encarceramento massivo e se referem à prisão como uma "caixa de esquecimento", para onde as pessoas são enviadas como objetos ou mercadorias: 
Essa Caixa de Esquecimento só se importa com quantidade, isto sim é importante a meu ver para essa tal Justiça. Mas manter pessoas aprisionadas não significa mudar uma Sociedade Sofrida, cheia de feridas marcadas por um deslize que vem de um passado muito presente, e que, de fato, nada mais somos que o resultado de um "Produto"...

O corpo é outro elemento central observado nos poemas. Muitas vezes, é nele em que se inscreve materialmente a memória da violência partilhada por algumas das autoras em suas trajetórias de vida. Os poemas "Por que eu?" (p. 89) e "Basta" (p. 35), escritos respectivamente por Mirian Baião Cambolo e Edvânia, identificam uma imensa dor associada a machucados e cicatrizes corporais:

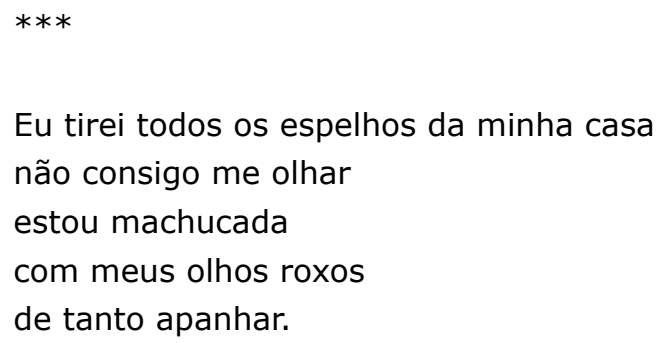
todas as minhas lembranças vêm junto com as minhas lágrimas. Eu luto todos os dias para superar esta etapa do meu passado.

Também é o corpo que sofre a experiência direta do aprisionamento, experiência contra a qual o conjunto das autoras busca, cada uma a seu modo, resistir, por meio da escrita. Ao tecer narrativas, sonham com a liberdade, ainda que seus corpos estejam fisicamente confinados. Os versos transcritos a seguir, primeiramente de Paola Sodré em "Liberta!" (p. 96) e, na sequência, de Schneider Mikaely em "Mãos Soltas" (p. 104), propõem essa dicotomia:

Olhos abertos ou fechados

um corpo trancado ou uma carne presa

em uma alma liberta!

Liberta para sonhar

convicta em planos que vão além

além de prisões

liberta! 
Com as mãos sem algemas, com os pés sem correntes, com o corpo presente... em uma prisão. Mas a mente que voa longe, com o olhar distante.

[...]

Alma que vaga, pelas ruas, pela praia... Com o corpo preso, mas a mente, não. Mente que voa, as mãos soltas.

Poemas de amor também são recorrentes na coletânea. Alguns aparecem endereçados aos companheiros de quem as autoras foram apartadas. Outros, são motivados por relações amorosas com mulheres igualmente encarceradas, relações que muitas vezes se apresentam como nova forma de amar e de resistir por meio do afeto - aos efeitos da prisão. Em "Rafaela" (p. 25), Daniela Vásquez dedica seus versos à companheira:

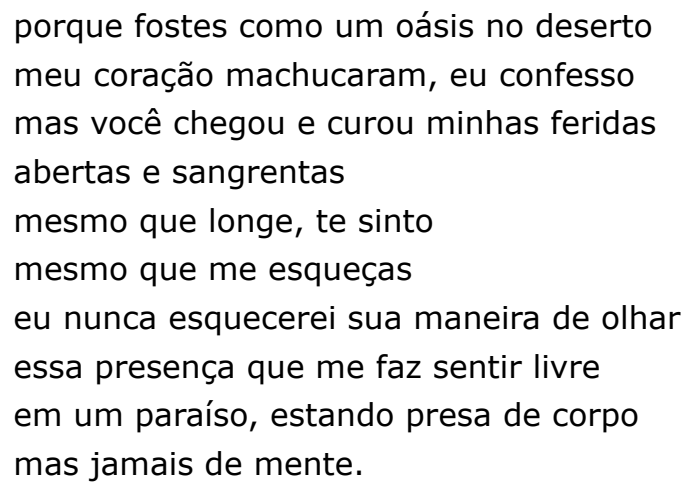

Fomos e somos como o sol depois da tempestade. Te amarei para sempre.

É possível observar por meio dos excertos anteriores que o livro Sarau Asas Abertas materializa o exercício da reflexão e da apropriação da linguagem literária. As vivências e memórias individuais das autoras combinam uma grande multiplicidade de vozes vivas e, assim, acabam por compartilhar memórias coletivas, marcadas pelo processo de privação de liberdade.

A coletânea de poemas expressa, ainda, a potência da literatura como espaço de encontros possíveis entre subjetividades diversas. De um lado, as autoras que, inspiradas pelo sarau Asas Abertas, resistem com seus poemas à exclusão 
e, de outro, leitoras e leitores que, graças à literatura, abrem-se a diferentes e desafiadoras experiências humanas.

\section{Considerações Finais}

O perfil da população prisional no Brasil é predominantemente masculino, negro e jovem. No entanto, enquanto a população carcerária masculina em geral subiu $220 \%$ entre os anos 2000 e 2014, o encarceramento feminino cresceu $567 \%$ no mesmo período (RIO GRANDE DO SUL, 2017, p. 5), o que mostra uma assimetria relacionada às condições de vulnerabilidade e violência a que as mulheres estão particularmente submetidas.

Excluídos historicamente dos processos de emancipação social, esses homens e mulheres que vivem no cárcere não alcançaram os lugares reservados à população branca e hegemônica. A opinião pública reforça nossa cultura racista e intolerante ao considerar descartáveis todos os que se encontram atrás das grades, pois seus corpos revelam o fracasso do Estado em promover igualdade social e bem-estar.

As mulheres encarceradas sofrem, além do estigma social, o abandono de seus companheiros e de outros familiares, como apontamos anteriormente, mas quando em contato com a arte, são capazes de resistir à invisibilidade e ao silenciamento a que são sujeitadas. Nesse sentido, o livro Sarau Asas Abertas, que apresenta poemas produzidos exclusivamente por mulheres em cumprimento de pena, demonstra como a criatividade permite alcançar os muros fora da prisão, seja por meio de textos verbo-visuais, como as colagens das capas e contracapas, seja por meio dos versos propriamente ditos.

O registro dos poemas participa da formação das modalidades de memória aqui apresentadas: memória individual, memória coletiva, memória pública. Individual na medida em que cada verso, cada estrofe, cada poema traz a marca de uma autoria definida, com uma história particular; coletiva, porque ajuda a manter as lembranças de terceiros que interessam ao coletivo e pública porque põe em circulação vozes dissonantes com o poder hegemônico. 
O resultado, em forma de livro, testemunha a ideia de Antonio Candido em seu antológico texto "Direitos Humanos e Literatura" (1989, p. 113): "A literatura confirma e nega, propõe e denuncia, apoia e combate, fornecendo a possibilidade de vivermos dialeticamente os problemas".

\section{Referências}

AGAMBEN, G. Estado de exceção: homo sacer II. São Paulo: Boitempo, 2004.

BAITELLO JUNIOR, N. Comunicação, mídia e cultura. Revista São Paulo em Perspectiva, São Paulo, v. 12, n. 6, p. 11-16, 1998.

BOSI, A. Narrativa e resistência. In: BOSI, A. Literatura e resistência. São Paulo: Companhia das Letras, 2002. p. 118-135.

CANDIDO, A. Direitos humanos e literatura. In: FESTER, A. C. R. (org.). Direitos humanos e... São Paulo: Brasiliense, 1989. p. 107-126.

COLETIVO POETAS DO TIETÊ. Sarau asas abertas: penitenciária feminina da capital. São Paulo: Edições do Tietê, 2019.

HALBWACHS, M. A memória coletiva. São Paulo: Editora Revista dos Tribunais, 1990.

HELLER, B.; VARGAS, H. Diários de Testemunhas: das memórias subjetivas aos produtos midiáticos. Revista Interamericana de Comunicação Midiática, Santa Maria, v. 19, n. 41, p. 36-57, 2020.

JELÍN, E. Exclusión, memorias y luchas políticas. In: JÉLIN, E. Estudios latinoamericanos sobre cultura y transformaciones sociales en tiempos de 
globalización. Buenos Aires: Consejo Latinoamericano de Ciencias Sociales, 2001. p. 91-110.

NASCIMENTO, L. Brasil tem mais de 773 mil encarcerados, maioria no regime fechado. Agência Brasil, [s. I.], 14 fev. 2020. Disponível em: bit.ly/3qNsSf9. Acesso em: 22 jan. 2021.

PETIT, M. A arte de ler ou como resistir à adversidade. São Paulo: 34, 2009.

RIO GRANDE DO SUL. Agenda nacional pelo desencarceramento 2017-2018. Porto Alegre: Comissão de Cidadania e Direitos Humanos, 2017.

SANGLARD, F. ; SANTA CRUZ, L. ; GAGLIARDI, J. Da comemoração à rememoração: retrotopia nos 55 anos do Golpe de 1964 na cobertura da Folha e do Globo. In: ENCONTRO ANUAL DA COMPÓS, 29., 2020, Campo Grande. Anais [...]. Campo Grande: Compós, 2020.

SARLO, B. Tempo passado. São Paulo: Companhia das Letras: Belo Horizonte: Editora UFMG, 2007.

SAWAIA, B. (org.). As artimanhas da exclusão: análise psicossocial e ética da desigualdade social. Petrópolis: Vozes, 2001.

SELIGMANN-SILVA, M. Violência, encarceramento, (in)justiça: memórias de histórias reais das prisões paulistas. Revista de Letras, Araraquara, v. 43, n. 2, p. 29-47, 2003. 